\title{
RADIO FREQUENCY IDENTIFICATION (RFID) BASED WIRELESS MANUFACTURING SYSTEMS, A REVIEW
}

\author{
Roza Dastres \\ Cyprus International University, Turkey \\ E-mail: roza.dastres@yahoo.com \\ Mohsen Soori \\ Eastern Mediterranean University, Turkey \\ E-mail:mohsen.soori@gmail.com \\ Mohammed Asamel \\ Eastern Mediterranean University, Turkey \\ E-mail: mohammed.asmael@emu.edu.tr
}

Submission: $11 / 22 / 2020$

Revision: 2/4/2021

Accept: 3/8/2021

\section{ABSTRACT}

Radio frequency identification (RFID) is one of the most promising technological innovations in order to track and trace products as well as material flow in manufacturing systems. High Frequency (HF) and Ultra High Frequency (UHF) RFID systems can track a wide range of products in the part production process via radio waves with level of accuracy and reliability. As a result, quality and transparency of data across the supply chain can be accurately obtained in order to decrease time and cost of part production. Also, process planning and part production scheduling can be modified using the advanced RFID systems in part manufacturing process. Moreover, to decrease the cost of produced parts, material handling systems in the advanced assembly lines can be analyzed and developed by using the RFID. Smart storage systems can increase efficiency in part production systems by providing accurate information from the stored raw materials and products for the production planning systems. To increase efficiency of energy consumption in production processes, energy management systems can be developed by using the RFID-sensor networks. Therefore, smart factories and intelligent manufacturing systems as industry 4.0 can be introduced by using the developed RFID systems in order to provide new generation of part production systems. In this paper, a review of RFID based wireless manufacturing systems is presented and future research works are also suggested. It has been observed that the research filed can be moved forward by reviewing and analyzing recent achievements in the published papers. 
Keywords: RFID, Wireless Communication, Manufacturing Systems

\section{INTRODUCTION}

Manufacturers are looking for innovative ways to minimize costs and optimize their activities due to rising operating costs. For mass production automation projects, radio frequency identification (RFID) can be an option which is a non-contact tool for data transmission in the recognition of objects. These wireless networks are being deployed to serve as "smart monitoring systems" that offer extensive tracking and tracking capabilities from manufacturing to the supply chain's final customer phases. Radio Frequency Identification Technology (RFID) is an automatic identification technology by using the wireless sensors, wireless communication and information network technologies in order to track and trace product, material flow in manufacturing systems.

RFID technology can improve the efficiency and reliability of a companies in part production process. RFID systems help avoid product and equipment shortages by generating real-time data; provide clients with reliable, on-time delivery or service; monitor inventory of parts; and provide field maintenance history by generating real-time data. RFID can tackle various production challenges, including security, quality control, execution of production and management of assets.

The aim is to use RFID to become a data-enabled organization, a manufacturer that gathers information and uses the data to further its competitive advantage. The difference between Manufacturing Execution Systems (MES), Enterprise Resource Planning (ERP) systems and the manufacturing floor can be bridged by using the advanced RFID. The technology is capable of delivering the enabling information at a far higher degree of precision, timeliness and detail than other alternatives.

To improve performance of manufacturing processes and to increase accuracy in produced parts, the RFID systems are used in a wide variety of applications. To increase efficiency in part manufacturing process, the advanced RFID systems can be applied to the process planning and part production scheduling systems. To decrease the time and cost of part production, the RFID can be applied to the material handling systems in order to present developed assembly in part production process.

Smart storage systems can increase efficiency in part production systems by providing accurate information from the stored raw materials and products for the production planning systems. To increase efficiency of energy consumption in production processes, energy 
management systems can be developed by using the RFID-sensor networks. To decrease the waste materials in part production process, RFID can be applied to prove a leaner manufacturing system. Production monitoring and controlling systems can be developed using RFID systems in order to increase accuracy and efficiency in part production process. Therefore, smart factories and intelligent manufacturing systems as industry 4.0 can be introduced by using the developed RFID systems in order to provide new generation of part production systems.

Understanding the determinants of RFID adoption in the manufacturing industry is reviewed by Wang et al. (2010) to present the effect and benefits of the RFID systems in developed manufacturing systems. A literature review, recent developments, and case studies in wireless manufacturing is presented by Huang et al. (2009) to highlight why and how manufacturers can benefit from applying wireless manufacturing solutions in addressing shop-floor challenges and facilitating contemporary manufacturing strategies.

Fundamentals, methodology and applications in RFID enabled manufacturing is reviewed by Lu et al. (2006) to increase capabilities of part production systems using RFID communication. Wireless chemical sensors and biosensors in chemical industries are reviewed by Kassal et al. (2018) to discuss challenges and examples for each of the major chemical sensor and major radio technologies related to different chemical industrial applications. A systematic literature review on RFID application in manufacturing and supply chain management is presented by Gotmare et al. (2019) to discuss the applications and future trend of the RFID systems in manufacturing systems.

Application of Radio Frequency Identification (RFID) in manufacturing in Malaysia is reviewed by Sulaiman et al. (2012) in order to be analyzed and modified. Implementing an RFID-based manufacturing process management system is analyzed by Ngai et al. (2012) to discuss effective factors in applications of the RFID systems in part production. Applications and techniques of the RFID systems is reviewed by Sanpechuda and Kovavisaruch (2008) in order to discuss and develop the applications of the RFID systems in industrial factories. Applications of the RFID and Sensing Techniques is reviewed by Cui et al. (2019) to increase the efficiency in process of part production.

To analyze and modify the machining operations in virtual environments, virtual machining systems and applications are presented by Soori et al. (2017; 2014; 2013; 2021; 2016). To analyze the mechanical behavior of materials in cutting operation as well as Friction Stir Welding (FSW) operations, recent development in research works are reviewed 
by Soori and Asamel (2020; 2020). To develop the application of the Computer Aided Process Planining systems in the manufacturing systems, a review in the recent research works is presented by Soori and Asamel (2021).

Application of the Secure Socket Layer in the Network and Web Security is investigated by Dastres and Soori (2020) to increase the security measures in the web of data. The impact of meltdown hole on various processors and operating systems are studied by Dastres and Soori (2020) in order to increase security of CPU manufacture by preventing the capturing data on computer or smartphones by attackers. . A review in recent development of network threat and security measures is presented by Dastres and Soori (2021) to classify the presented research works and suggest some future research trends. Advanced image processing systems is reviewed by Dastres (2021) and Soori to introduce new techniques in the image processing systems.

In the present research work, different issues of research works in the RFID based wireless manufacturing systems are categorized to provide a useful study for the researchers in the interesting field. As a result, new ideas for RFID applications in manufacturing systems and gaps in the existing literature are obtained and future research works are also suggested in order to push forward this interesting research field.

Just In Time (JIT) manufacturing, Real-Time wireless manufacturing, Material handling systems, RFID-based lean manufacturing, Smart storage systems, Supply chain management, Product assembly planning, Production monitoring and controlling systems, Applications of the RFID in industry 4.0, Wireless sensor networks in manufacturing systems, Energy management in RFID-sensor networks, Production planning and scheduling using RFID Systems and Performance improvement in manufacturing systems are categorized as different issues of research works in RFID applications in manufacturing systems.

Section 2 presents a review from research works related to RFID application manufacturing systems. In the section 3, research works are classified according to the different topics in research to the RFID application manufacturing systems and future research works in the RFID systems are also suggested.

\section{DIFFERENT APPLICATIONS OF RADIO FREQUENCY IDENTIFICATION (RFID) BASED WIRELESS MANUFACTURING SYSTEMS}


The research works in the field of RFID based wireless manufacturing systems is recently developed in different topics in order to increase quality as well as efficiency in the part production. Several approaches are recently developed in the generative RFID systems. The different topics of research works are classified in this section in order to review their achievements in the research field.

\subsection{Just In Time (Jit) Manufacturing}

To enhance manufacturers' competitiveness through inventory and lead time reduction, the Just-in-time manufacturing is introduced. To implement the JIT in the manufacturing systems, some challenges such as, frequent and real-time information sharing and communication between different functional departments, responsive action for adjusting the production plan against the continually changing manufacturing situation should be analyzed and solved. The RFID is a useful device to modify the JIT systems in order to develop the manufacturing systems.

In order to increase manufacturers' competitiveness through inventory and lead time reduction, application of the Internet of Things in developing the Just-in-Time Manufacturing operations is investigated by $\mathrm{Xu}$ and Chen (2016). The application of RFID systems in cost tracking of part production is presented by Ramadan et al. (2017) to evaluate and decrease the cost of part production using the RFID systems. The application of smart RFID systems using JIT process in the food industries is investigated by Chen and Chen (2017) to provide raw materials and increase customer satisfaction in produced and presented foods.

The application of the RFID and JIT systems in manufacturing process of the automotive parts and assembly line of the car manufacturing companies is developed by Huang et al. (2010) to increase efficiency in process of part production. In order to improve the connectivity of production chains and responsive production scheduling capability, the effects of the JIT in efficiency enhancement of the part manufacturing using the Internet of things is analyzed and investigated by $\mathrm{Xu}$ and Chen (2018). An Internet of Things based framework and IRID system is developed by Xu and Chen (2018) in order to enhance just-intime manufacturing in process of part production.

\subsection{Real-time wireless manufacturing}

To obtain the real time production data from the part production process, the advanced RFID systems can be implemented. As a result, it is possible to increase the monitoring and 
analyzing capabilities using the RFID based real time production data systems in order to increase accuracy as well as efficiency in part production process. In the presented study by the Zhang et al. (2011), different manufacturing resources is analyzed using advanced RFID/Auto-ID devices to capture real-time production data in part manufacturing systems.

To obtain the real time production data using the RFID based monitoring system for a particular shop floor operation, the dynamic manufacturing processes is analyzed by Chen et al. (2010). A real time data from manufacturing projects using the RFID system is obtained by Zhang et al. (2010) to define and execute a real-time reconfigurable manufacturing project. In order to provide optimal production management in manufacturing projects, application of the RFID systems in real time manufacturing tracking is investigated by Zhang et al. (2012).

To obtain the real time production data and decrease the training time in part manufacturing systems, the OS-ELM based indoor positioning system using the RFID system is developed by Yang et al. (2016). The developed algorithm of the OS-ELM based indoor positioning system is shown in the figure 1 Yang et al. (2016).

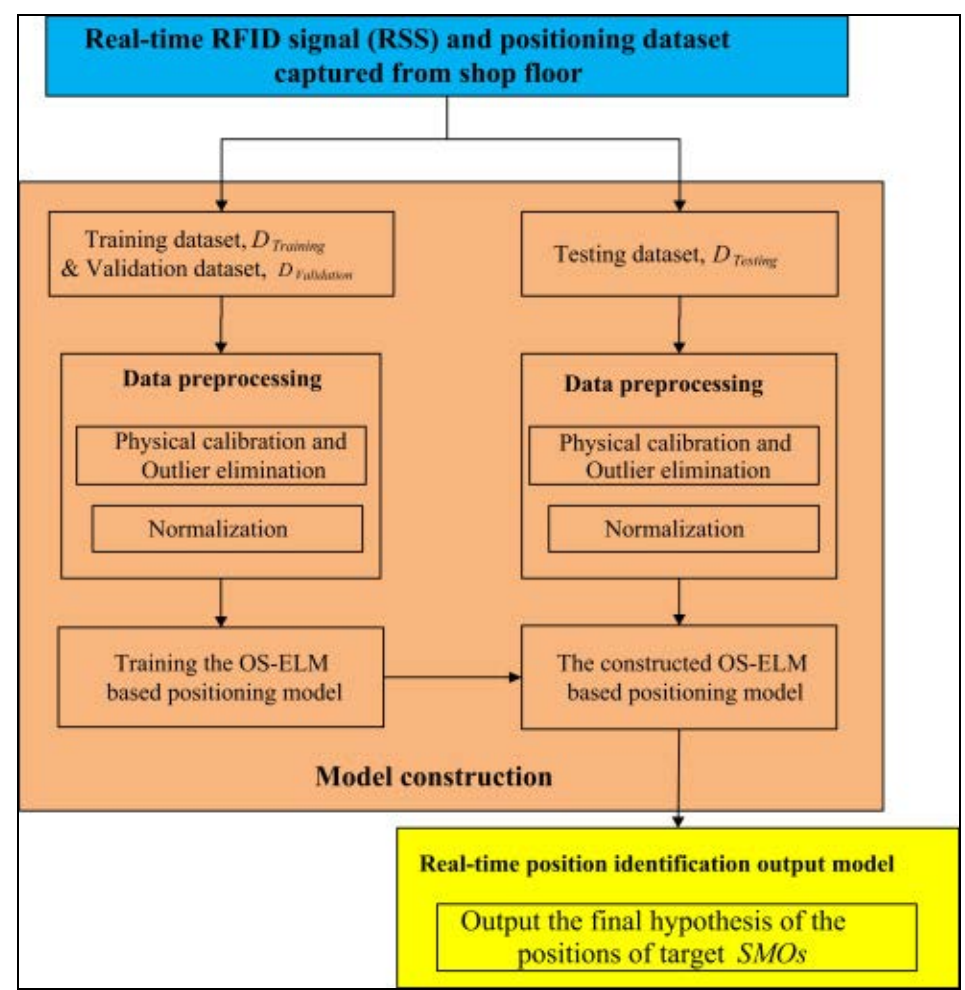

Figure 1: The developed algorithm of the OS-ELM based indoor positioning system Source: Yang et al. (2016). 
Radio frequency identification-enabled monitoring and evaluating in the discrete manufacturing process is developed by Yuan et al. (2017) to track and monitor the work-inprocess of manufacturing systems. Wireless SMART product tracking using radio frequency identification is developed by Jardine et al. (2019) in order to access valuable information of products monitoring during and after the production process.

\subsection{Material handling systems}

To decrease the cost of material handling in the part manufacturing systems which has a big portion of product cost, the RFID systems can be applied. Application of the RFID system in material handling system is shown in figure 2.

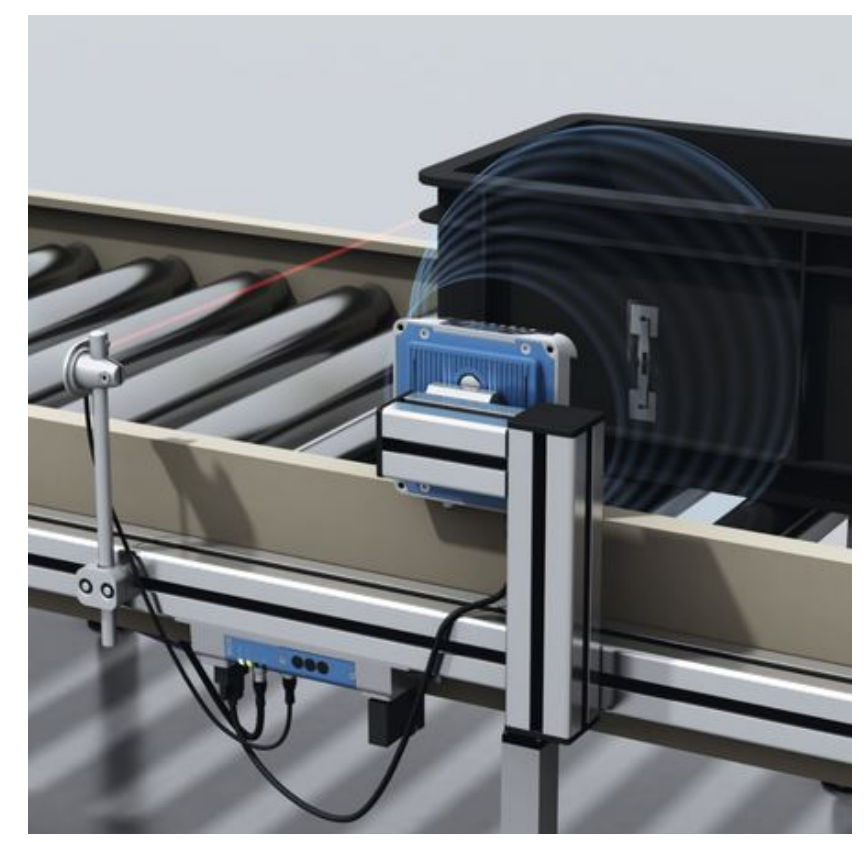

Figure 2: Application of the RFID system in material handling system.

The RFID systems is applied to the material handling system of automobile parts by Jamaluddin et al. (2018) to decrease time of material handling between the parts manufacturer and its vendors in car companies. To decrease the time and cost of martial handling in part production systems, the material delivery system is analysed and optimized by Zhao et al. (2018). To analyze and decrease time of material handling in the part production process, the advanced RFID system for mass-customization production is presented by Zheng et al. (2013). RFID-enabled real-time of shop-floor management is shown in the figure 3 Zheng et al. (2013). 


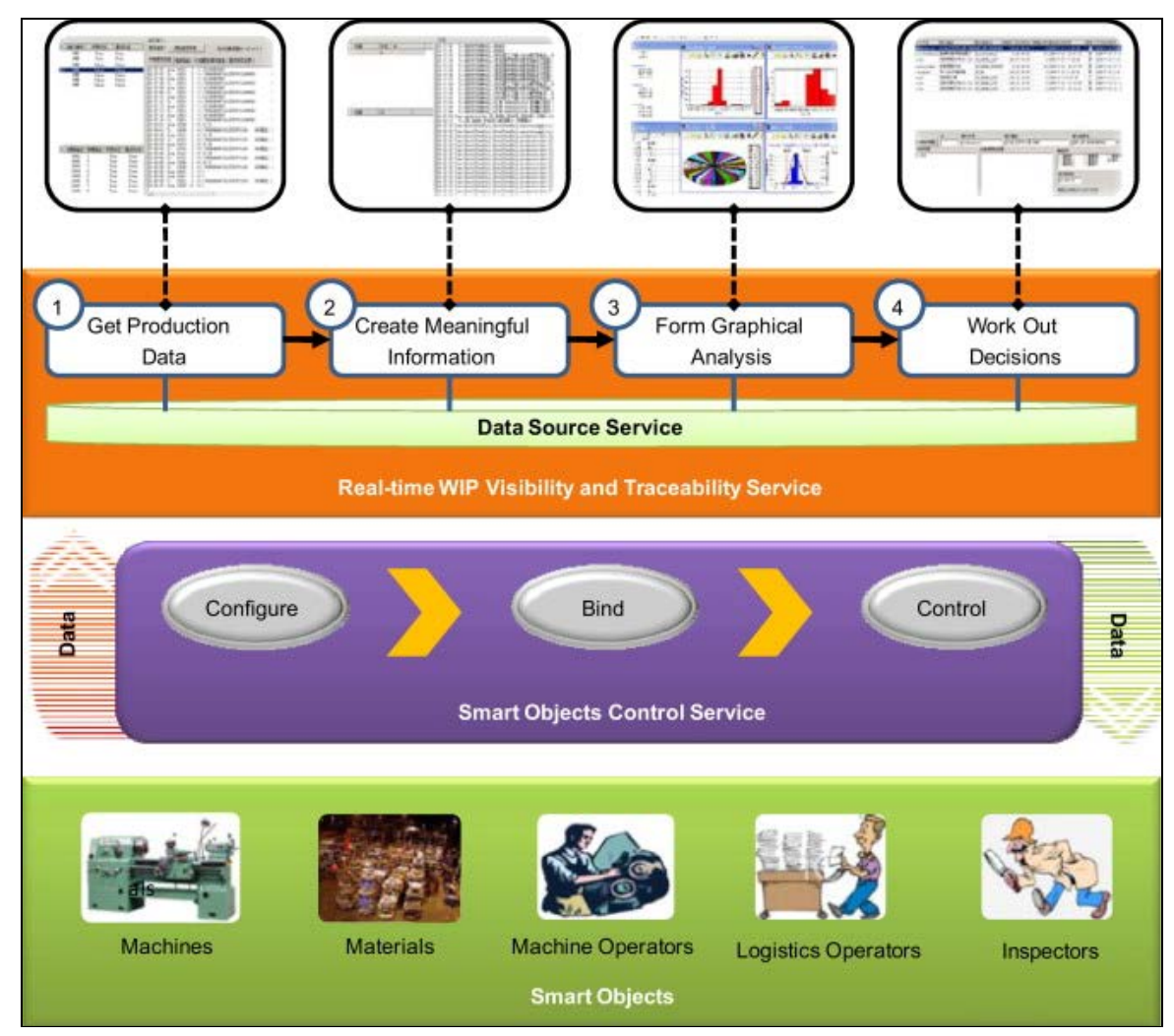

Figure 3: RFID-enabled real-time management Source: Zhong et al. (2013).

Application of the RFID systems in industrial sites of part production systems is developed by Chai et al. (2017) to increase the effects of the reference tag systems using the RFID. Also, an advanced RFID-Aided tracking system is implemented by Moon et al. (2018) in order to present an efficient material tracking system in material handling process. To develop the applications of the RFID in material handling of automobile assembly systems, an algorithm for the advanced software is presented by Zheng et al. (2020).

In order to decrease cost and time of material handling in the manufacturing systems, the accuracy of positioning in the AGV system is developed by using the RFID positioning system in the presented study by $\mathrm{Lu}$ et al. (2017). Efficiencies in the on-site material handling process by using radio frequency identification in the wood building construction industry is developed by Lindblad et al. (2018) to minimize damages in process of material handling systems. Conceptual model and cloud-based scheduling of handling activities is developed by Sgarbossa et al. (2020) in order to increase the flexibility and productivity of the overall manufacturing system. 


\subsection{RFID-Based Lean Manufacturing}

To minimize the waste materials in part production process, lean manufacturing systems are introduced. The RFID can develop the lean manufacturing systems by tracking products and material flow in manufacturing systems in order to decrease cost of produced parts. To provide lean production system using the worker management, an automatic RFID monitoring systems for workers in the industrial environments is presented by Sun et al. (2010).

To increase efficiency in part production process, applications of the RFID systems in the lean manufacturing is developed by Chen et al. (2011). To decrease the waste materials in part manufacturing systems, an advanced RFID for leaner manufacturing is investigated by Brintrup et al. (2010). In order to provide a leaner manufacturing system, applications of the RFID systems to lean manufacturing is investigated by Saygin and Sarangapani (2011). The applications of the internet of things as well as RFID systems in decreasing the waste materials using the energy Company's budget management in part production process is presented by Aydos and Ferreira (2016).

To decrease the waste materials in part production process, applications of the RFID technology in lean manufacturing is investigated by Haddud and Lee (2013). Material flow control in lean manufacturing applications using the RFID systems is investigated by Ramadan et al. (2016) to reduce the total cycle time in part production process. RFID Systems within a lean supply chain in a global environment is investigated by Smith et al. (2018) in order to decrease the waste materials in manufacturing systems.

\subsection{Smart storage systems}

The smart storage systems are recently developed in order to decrease time and cost of stored materials in production systems. The RFID are applied to the smart storage systems to obtained accurate data and improve the part production scheduling process. As a result, more efficient and effective methods for storing, picking and dispatching goods in part production process are introduced by applying RFID to the smart storage systems.

Application of the RFID system in managing the warehouses is developed by Chen et al. (2013) to improve efficiency in advanced material storage systems. The warehouse systems in material handling operations using the RFID is developed by Alyahya et al. (2016) to improve efficiency in material-handling operations. To provide decision making in the 
complex conditions of storage assignment in a smart warehouse, applications of the RFID systems for enhancing the efficiency of order picking is investigated by Choy et al. (2017).

The product class-based storage and potential fields methods using the RFID systems are implemented by Trab et al. (2018) to present a safe and secure product storage methods in smart warehouses. To discuss the benefits, obstacles and future trend of the RFID systems in the smart storage systems, application of the RFID in the warehouse is reviewed by Lim et al. (2013). The applications of the RFID systems in smart warehouses is investigated by Osyk et al. (2012) to develop the impact of the RFID to warehousing industries. Smart Warehouse Management Based on IoT Architecture and RFID system is presented by Sung and Lu (2018) to monitor the internal conditions of the warehouse to ensure the safety of the goods.

\subsection{Supply Chain Management}

To enhance supply chain management and improve decision making in part production process, RFID systems can be applied. Various modules of the supply chain such as inventory management, asset management, warehouse operation, manufacturing processes and retail marketing can be developed using the RFID systems in order to increase efficiency in manufacturing systems. A literature review of the emerging field of IOT using RFID and its applications in supply chain management is presented by Naskar et al. (2020) to build automated and interconnected smart manufacturing environment. RFID and ERP systems in supply chain management is investigated by Oghazi et al. (2018) to enhance the information flow across the supply chain management process.

Applications of the RFID system in management of supply chain and its associated logistics is investigated by Cheung et al. (2008) to develop the RFID applications in part manufacturing systems. To decrease the waste materials in lean production systems using the RFID based supply chain management, the developed RFID systems in part manufacturing systems is presented by Chen et al. (2013).

To increase efficiency in logistics supply chain visibility and tracking of raw materials from suppliers in manufacturing systems, the developed track and trace in supply chain management based on RFID and GPS (Global Positioning System) is presented by He et al. (2009). To develop the RFID applications in supply chain management, new software for the resource analysis is presented by the Leung et al. (2014). To provide recent development and challenges and suggest future research works in supply chain management, a review of RFID in supply chain management is presented by Musa and Dabo (2016). 


\subsection{Product assembly planning}

Assembly methods and strategies of part production process can be analyzed and modified using the advanced RFID systems in order to increase added values in part manufacturing processes.

The process of electronic parts assembly planning for the large air conditioner systems using the RFID is developed by Qu et al. (2012) to enhance the efficiency in part production process. The application of RFID systems in assembly process of fixed-position layouts considering the working space area is investigated by Huang et al. (2007) in order to provide an advanced material and manpower flows in production process. Developed wireless manufacturing systems in the study is presented in the figure 4 Huang et al. (2007).

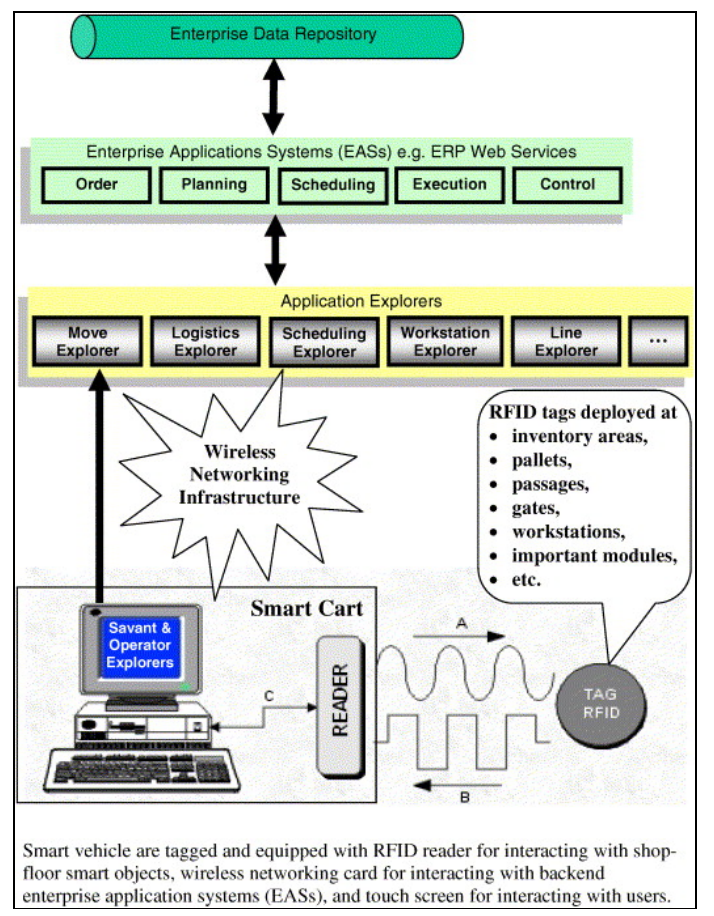

Figure 4: Conceptual architecture of wireless manufacturing Source: Huang et al. (2007).

To analyze the workstations, critical tools, key components, the RFID systems is implemented by Huang et al. (2008) in order to provide adaptive assembly planning and control in part manufacturing systems. To increase efficiency in assembly process of part production, RFID-enabled smart assembly management system is developed by Qu et al. (2013).

To develop the application RFID systems in welding operations using industrial robots, RFID based robotic assembly system in mix manufacturing operations is developed 
by Makris et al. (2012). Flexible assembly lines using RFID systems is developed by Wang et al. (2010) to analyze and modify the assemble process of sophisticated parts. Loncin motorcycle assembly line is analyzed and modified by Liu et al. (2012) in order to improve the productivity and quality in assembly systems using RFID systems.

Monitoring and controlling the complex product assembly process using mobile agents and RFID systems is presented by Sun et al. (2009) to solve the asynchrony problem between the logistics stream and the information stream in the complex product assembly executive process. An Internet of Things-enabled BIM platform using RFID systems for onsite assembly services in prefabricated construction is developed by $\mathrm{Li}$ et al. (2018) to improve the efficiency and effectiveness of daily operations, decision making operations in part manufacturing systems.

\subsection{Production monitoring and controlling systems}

To increase accuracy in part production process, monitoring and controlling systems using the RFID can be implemented. Application of the RFID system in cutting tool monitoring system is shown in the figure 5.

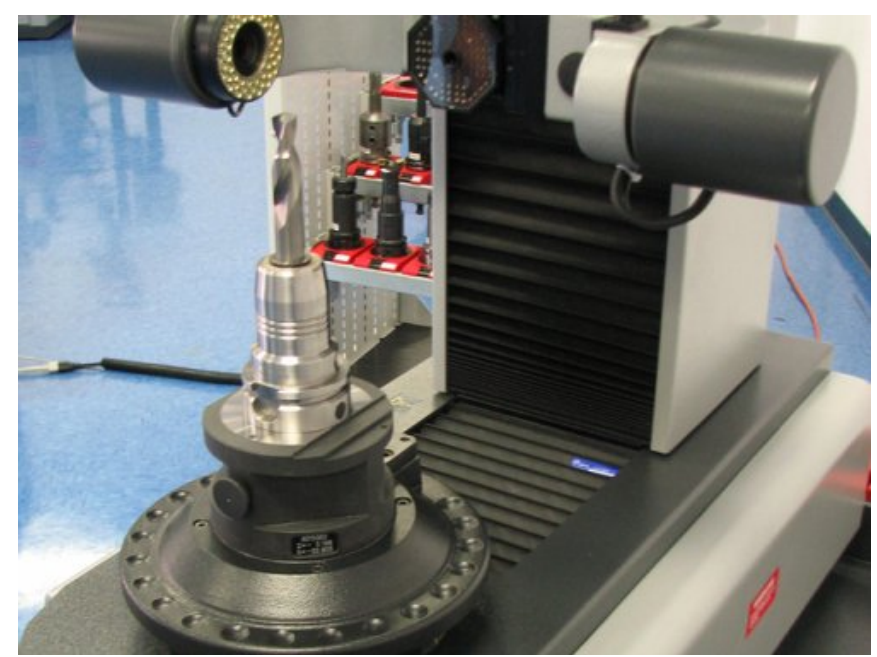

Figure 5: Application of the RFID system in cutting tool monitoring system.

Production monitoring and scheduling in a distributed manufacturing environment is investigated by Guo et al. (2015) in order to present an intelligent decision support system using advanced RFID systems. The remote wireless RFID system using Android platform is developed by Truong and Vu (2012) in order to increase accuracy as well as efficiency in part production process. 
A review in applications of the RFID systems is developed by Zhou et al. (2017) to provide a better understanding of past achievements and future trends of production monitoring towards energy-efficient manufacturing. In order to obtain the real-time machine condition data and energy consumption of pumps in manufacturing machines, process monitoring system is developed by $\mathrm{Wu}$ et al. (2017). Fog-Based Cyber-Manufacturing Systems developed in the study is shown in the figure 6 Wu et al. (2017).

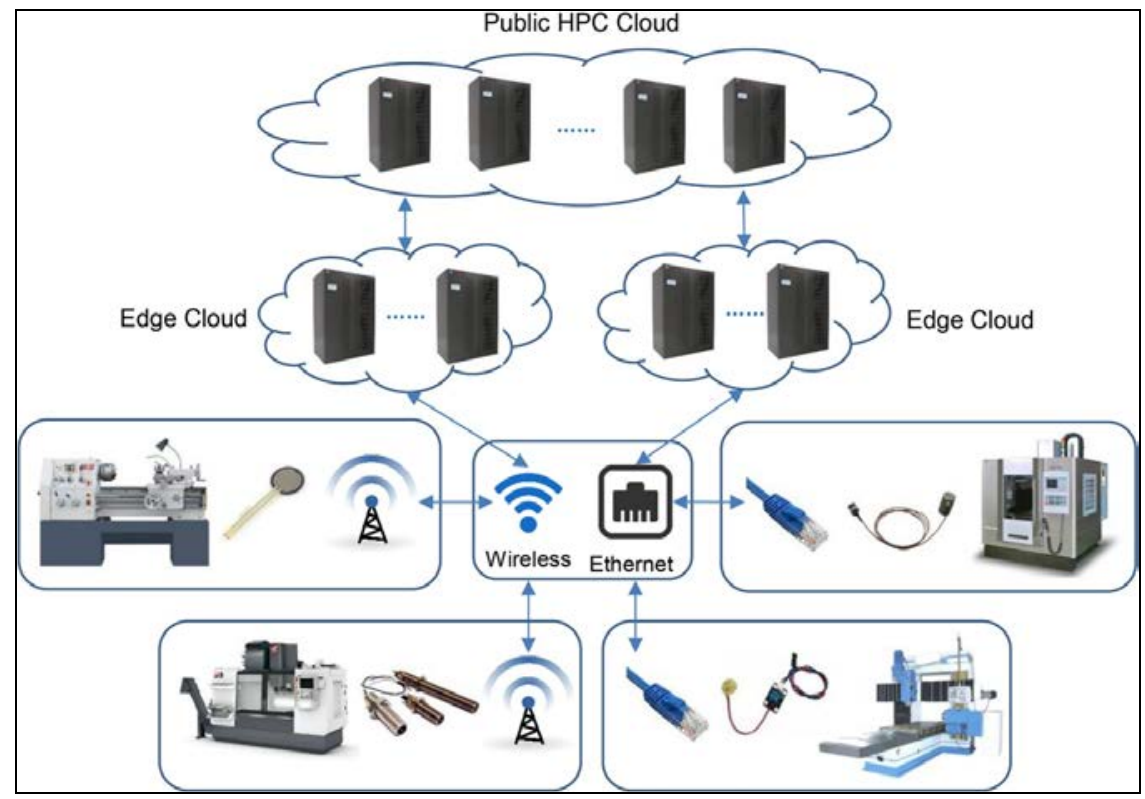

Figure 6: An Infrastructure Architecture for Fog-Based Cyber-Manufacturing Systems Source: Wu et al. (2017).

The energy consumption of the machining process using advanced RFID system is analyzed and decreased by Mourtzis et al. (2016) to increase efficiency in energy consumption of the machine tools in part production process. To implement a value stream map (VSM) in a lean environment by automating the collection and distribution of production data, the advanced monitoring and controlling system is developed by Chen et al. (2012). To enhance flexibility and configurability in manufacturing system, a multi-agent RFID-enabled distributed control system for a flexible manufacturing shop is investigated by Barenji et al. (2014).

Production process of complex parts using advanced RFID system is analyzed and modified by Chen (2012) to present an advanced wireless RFID based monitoring and controlling system in manufacturing systems. RFID-enabled social manufacturing system for inter-enterprise monitoring and dispatching of integrated production and transportation tasks is presented by Ding et al. (2018) to increase efficiency in process of part production. 
Chipless RFID sensor for angular rotation monitoring is developed by Genovesi et al. (2018) in order to increase accuracy and reliability in process of part production.

\subsection{Applications of the RFID in industry 4.0}

The industry 4.0 is the next step for the manufacturing industries by providing the smart products and digital factories. The RFID systems can be applied to the industry 4.0 to increase capabilities and flexibilities of the smart factories as well as intelligent manufacturing systems. To increase efficiency in the fourth industrial revolution, application of the UHF based RFID systems in Industry 4.0 using DoA estimation techniques is presented by Ascher et al. (2016).

To provide an intelligent, flexible and adaptive communication system in the fourth industrial revolution, an intelligent UHF-RFID reader considering the Industry 4.0 applications is developed by Lechner et al. (2016). To describe the application of the RFID systems in the fourth industrial revolution, a review in intelligent manufacturing in applications of industry 4.0 is presented by Zhong et al. (2017). Applications of the transmission belts in the Industry 4.0 is analyzed by Albrecht et al. (2015) to increase thermal and mechanical behavior of the tools in part production using advanced RFID systems.

To provide configurability, flexibility, and customizability in developed manufacturing systems, smart guided vehicles in Industry 4.0 applications is developed by Mehami et al. (2018). To present advanced sensor systems in the fourth industrial revolution, RFID based sensor platform for industry 4.0 application is presented by Petrov et al. (2019). To decrease the cost of martial storage in the advanced manufacturing systems using advanced RFID systems, CPS-Based smart warehouse for Industry 4.0 is investigated by Liu et al. (2018).

To design an industrial wireless networks under Industry 4.0, a review of industrial wireless networks is presented by Li et al. (2017). To monitor and gain access to production information for Industry 4.0 applications, wireless SMART Product Tracking using Radio Frequency Identification is investigated by (2019). Industry 4.0 adoption as a moderator of the impact of lean production practices on operational performance improvement by Tortorella et al. (2019) in order to manage the waste materials in process of part manufacturing. 


\subsection{Wireless sensor networks in manufacturing systems}

To detect and obtain data from the products as well as material flow in manufacturing systems, wireless sensor networks (WSNs) can be deployed. Deployment of large population of sensors for sophisticated sensing and control in the part production systems is recently considered in different research works.

To monitor and analyze the health condition of manufacturing machines, wireless sensor networks is investigated by Ota and Wright (2006). To develop the applications of advanced wireless sensor networks, a review of advanced algorithms for distributed wireless sensor networks in manufacturing systems is presented by Franceschini et al. (2009). To improve resource management and energy efficiency in manufacturing systems, methodology for monitoring manufacturing environment by using wireless sensor networks and the internet of things is developed by Li and Kara (2017).

To decrease the cost of part production by analyzing the transportation conditions, decision models and optimization of logistics systems operations in RFID-wireless sensor networks integration is investigated by Mejjaouli and Babiceanu (2015). To increase efficiency in a discrete manufacturing environment, wireless sensor network in industrial automation is developed by Zurawski (2009).

To monitor the surface finish, tool wear and vibrations of the machine tool during machining operations, advanced monitoring system in end-milling operations using wireless sensor networks is developed by Paul et al. (2008). Application of the RFID systems and wireless sensor networks in food manufacturing industries is investigated by Alfian et al. (2017) to optimize food distribution system. The developed food traceability system architecture is shown in the figure 7 Alfian et al. (2017). 


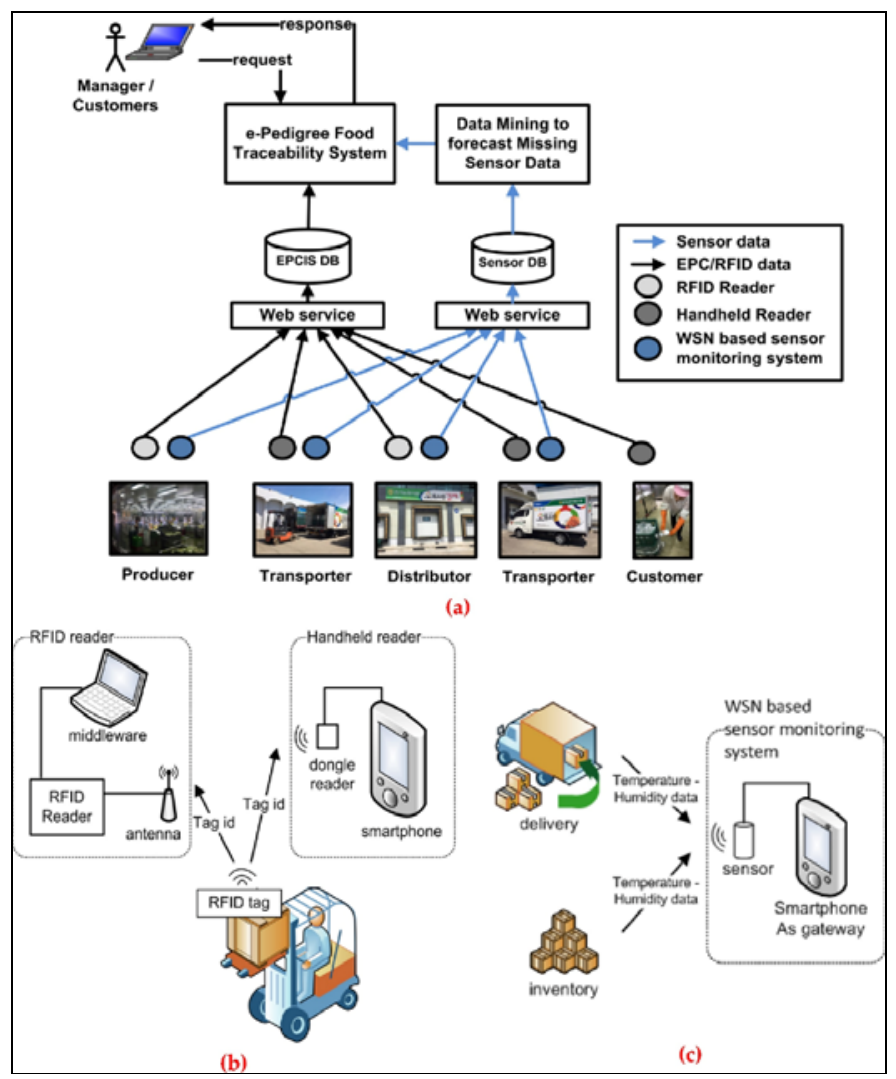

Figure 7: (a) Proposed e-pedigree food traceability system architecture, (b) RFID and handheld reader to read RFID tag, (c) sensor reads temperature-humidity from cold storage Source: Alfian et al. (2017).

\subsection{Energy management in RFID-sensor networks}

The energy management systems are designed and developed for efficient use of energy in manufacturing systems. To increase efficiency of energy consumption in production processes, energy management systems can be developed by using the RFIDsensor networks. As a result, new generation of manufacturing systems with energy-efficient conditions are generated in order to decrease cost and time of part production.

To enhance the efficiency in part production by analyzing the energy consumption in machine tools, energy management in rfid-sensor networks is investigated by Anjum et al. (2017). To discuss the challenges in the energy efficient systems of part production process, a Review on energy management systems using wireless sensor networks is presented by Babayo et al. (2017). To save more energy in manufacturing systems, energy management systems using RFID sensors with RF-Energy harvesting is developed by Iannello et al. (2010). 
To develop the renewable energy harvesting system in different industrial applications, applications of the wireless sensors networks using passive RFID tag technology is reviewed by Ferdous et al. (2016). An advanced hybrid power management unit for passive UHF RFID is presented by Sun et al. (2017) to increase the applications of RFID systems in part production process. To reduce the energy consumption during part design and production process, applications of internet of Things as well as RFID systems in product life-cycle energy management is developed by Tao et al. (2016).

Advanced electric vehicle batteries using RFID techniques is presented by Liu et al. (2012) in order to modify the production process of electric vehicles using the new generation of the vehicle batteries using RFID systems. A review in energy harvesting techniques for wireless sensor networks/radio-frequency identification systems is presented by Alsharif et al. (2019) to provide clear insights into eco-sustainable and green IoT technologies in advanced manufacturing systems.

\subsection{Production planning and scheduling using rfid systems}

Process of production planning and scheduling are recently developed by using the accurate date obtained from the RFID systems in part manufacturing process. As a result, more added values can be achieved by using the RFID systems in part production process.

To modify process planning and scheduling in part production process, advanced production planning and scheduling model for RFID-enabled ubiquitous manufacturing is developed by Zhong et al. (2015). RFID-enabled real-time ubiquitous manufacturing shop floor is developed in the study as shown in the figure 8 Zhong et al. (2015).

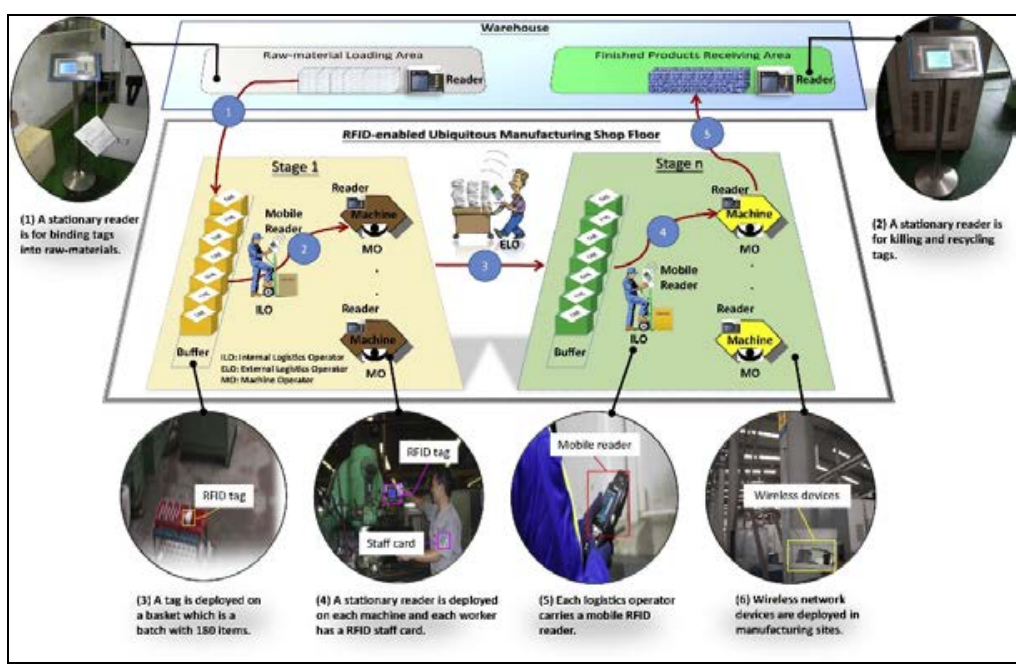

Figure 8: RFID-enabled real-time ubiquitous manufacturing shop floor Source: Zhong et al. (2015). 
To introduce an intelligent decision making system in part production process, aeofencing algorithms as well as RFID systems are investigated by Oliveira et al. (2015). Application of RFID system in advanced planning and scheduling algorithm for decision making in part production is investigated by Zhong et al. (2013) to connect and modify the different decision making systems across production processes. In order to decrease cost of part production and develop the production planning and scheduling in manufacturing systems, the RFID technology is implemented by Fan et al. (2015).

To analyze raw data obtained from the production logic and time series in part production process, application of the RFID technology in big data analysis in cloud manufacturing systems is investigated by Zhong et al. (2016). To develop the decision making algorithm in supply chain applications, multiple group of decision making system in the fuzzy environment is investigated by Chuu (2009).

Application of RFID technology in the decision making in steel manufacturing companies is studied by David et al. (2012) to increase efficiency in part production using casting process. To generate Pareto optimal solutions in multi-objective production planning problems, an advanced decision-making model using RFID technology is presented by Wong et al. (2014). Integrated production planning and control system for a panelized home prefabrication facility using simulation and RFID is investigated by Altaf et al. (2018) to optimize the production schedule.

\subsection{Performance improvement in manufacturing systems}

The performances of part manufacturing systems can be analyzed and modified by using the obtained data from the RFID systems. An advanced RFID system is introduced by Wang (2014) to decrease time and cost of part production in order to increase performance of manufacturing systems. To increase efficiency in manufacturing systems, impact of RFID technology utilization on operational performance is presented by Jaska et al. (2010).

To increase efficiency in manufacturer's shop floor process, the performance of a discrete manufacturing process using RFID is evaluated by Arkan and Landeghem (2013). To analyze and modify the current manufacturing systems, RFID systems is applied to the realtime reconfigurable manufacturing systems in the presented study by Zhang et al. (2010). To analyze and improve the production process of cloth manufacturing industries, application of the RFID in textile and clothing manufacturing systems is discussed by Nayak et al. (2015). 
In order to develop the part production process, effects of the of RFID on efficiency of manufacturing system is presented by Zelbst et al. (2012). RFID technology as a strategic tool towards higher performance of supply chain operations in textile and apparel industry of Malaysia is presented by Ali and Haseeb (2019) to increase productivity in process of part production. Improving multi-agent manufacturing control system by indirect communication based on ant agents is presented by Vatankhah Barenji and Vatankhah Barenji (2017) in order to improve the performances of manufacturing systems. Recent development of the RFID applications in manufacturing systems is shown in the Table 1.

Table 1: Recent development of the RFID applications in manufacturing systems

\begin{tabular}{|c|c|c|}
\hline Topic of research work & Papers & Finding/ Discoveries \\
\hline \multirow{3}{*}{$\begin{array}{l}\text { Just In Time (JIT) } \\
\text { manufacturing }\end{array}$} & Zhang et al. (2008) & $\begin{array}{l}\text { To increase efficiency in shop-floor manufacturing } \\
\text { objects, RFID-based smart Kanbans for Just-In-Time } \\
\text { manufacturing is developed. }\end{array}$ \\
\hline & $\begin{array}{l}\text { Ramadan et al. } \\
\text { (2017) }\end{array}$ & $\begin{array}{l}\text { RFID-enabled smart real-time manufacturing cost tracking } \\
\text { system is presented. }\end{array}$ \\
\hline & Huang et al. (2010) & $\begin{array}{l}\text { RFID-enabled real-time manufacturing for automotive part } \\
\text { and accessory suppliers is investigated. }\end{array}$ \\
\hline \multirow{3}{*}{$\begin{array}{l}\text { Real-Time wireless } \\
\text { manufacturing }\end{array}$} & Zhang et al. (2011) & $\begin{array}{l}\text { Agent-based Smart Gateway for RFID-enabled real-time } \\
\text { wireless manufacturing is developed. }\end{array}$ \\
\hline & Yang et al. (2016) & $\begin{array}{l}\text { To obtain the real time production data and decrease the } \\
\text { training time in part manufacturing systems, the OS-ELM } \\
\text { based indoor positioning system using the RFID system is } \\
\text { developed. }\end{array}$ \\
\hline & Zhang et al. (2012) & $\begin{array}{c}\text { RFID-enabled real-time manufacturing information } \\
\text { tracking infrastructure for extended enterprises is } \\
\text { investigated. }\end{array}$ \\
\hline \multirow{3}{*}{$\begin{array}{l}\text { Material handling } \\
\text { systems }\end{array}$} & Zhao et al. (2018) & $\begin{array}{l}\text { A Framework for shop floor material delivery } \\
\text { optimization based on RFID-Enabled production big data } \\
\text { is presented. }\end{array}$ \\
\hline & Moon et al. (2018) & $\begin{array}{l}\text { RFID-Aided tracking system to improve work efficiency } \\
\text { of scaffold supplier is investigated. }\end{array}$ \\
\hline & Lu et al. (2017) & $\begin{array}{l}\text { A RFID-enabled positioning system in automated guided } \\
\text { vehicle for smart factories is developed. }\end{array}$ \\
\hline \multirow{3}{*}{$\begin{array}{l}\text { RFID-based lean } \\
\text { manufacturing }\end{array}$} & Chen et al. (2011) & $\begin{array}{l}\text { Logistics efficiency improvement with lean management } \\
\text { and RFID application is investigated. }\end{array}$ \\
\hline & Aydos et al. (2016) & $\begin{array}{l}\text { RFID-based system for lean manufacturing in the context } \\
\text { of internet of things is investigated. }\end{array}$ \\
\hline & $\begin{array}{l}\text { Ramadan et al. } \\
\text { (2016) }\end{array}$ & $\begin{array}{l}\text { To reduce the total cycle time in part production process, } \\
\text { RFID-Enabled Real-Time dynamic operations and } \\
\text { material flow control in lean manufacturing is } \\
\text { investigated. }\end{array}$ \\
\hline \multirow{3}{*}{ Smart storage systems } & $\begin{array}{l}\text { Liu Guidong et al. } \\
\text { (2006) }\end{array}$ & $\begin{array}{l}\text { Resource management with RFID technology in automatic } \\
\text { warehouse system is presented. }\end{array}$ \\
\hline & $\begin{array}{l}\text { Chen Cheng Huang } \\
\text { et al. (2013) }\end{array}$ & $\begin{array}{l}\text { To improve the efficiency and effectiveness of warehouse } \\
\text { management, warehouse management with lean and RFID } \\
\text { application is presented. }\end{array}$ \\
\hline & Choy et al. (2017) & $\begin{array}{l}\text {. A RFID-based storage assignment system for enhancing } \\
\text { the efficiency of order picking is investigated. }\end{array}$ \\
\hline \multirow{2}{*}{$\begin{array}{l}\text { Supply chain } \\
\text { management }\end{array}$} & Oghazi et al. (2018) & $\begin{array}{l}\text { To enhance the information flow across the supply chain } \\
\text { management process, the RFID systems are developed. }\end{array}$ \\
\hline & Chen et al. (2013) & Supply chain management with lean production and RFID \\
\hline
\end{tabular}




\begin{tabular}{|c|c|c|}
\hline & & application is investigated. \\
\hline & $\begin{array}{l}\text { Musa and Dabo } \\
\quad \text { (2016) }\end{array}$ & $\begin{array}{l}\text { To provide recent development and challenges and suggest } \\
\text { future research works in supply chain management, a } \\
\text { review of RFID in supply chain management is presented. }\end{array}$ \\
\hline \multirow{3}{*}{$\begin{array}{l}\text { Product assembly } \\
\text { planning }\end{array}$} & Qu et al. (2013) & $\begin{array}{l}\text { To increase efficiency in assembly process of part } \\
\text { production, RFID-enabled smart assembly management } \\
\text { system is developed. }\end{array}$ \\
\hline & Makris et al. (2012) & $\begin{array}{l}\text { To develop the application RFID systems in welding } \\
\text { operations using industrial robots, RFID driven robotic } \\
\text { assembly for random mix manufacturing is developed. }\end{array}$ \\
\hline & Li et al. (2018) & $\begin{array}{l}\text { To improve the efficiency and effectiveness of daily } \\
\text { operations, decision making operations in part } \\
\text { manufacturing systems, RFID systems are developed. }\end{array}$ \\
\hline \multirow{3}{*}{$\begin{array}{l}\text { Production monitoring } \\
\text { and controlling systems }\end{array}$} & Budak et al. (2007) & $\begin{array}{l}\text { Design of an RFID-based manufacturing monitoring and } \\
\text { analysis system is investigated. }\end{array}$ \\
\hline & Wu et al. (2017) & $\begin{array}{l}\text { A fog computing-based framework for process monitoring } \\
\text { and prognosis in cyber-manufacturing systems is } \\
\text { investigated. }\end{array}$ \\
\hline & Barenji et al. (2014) & $\begin{array}{l}\text { A multi-agent RFID-enabled distributed control system for } \\
\text { a flexible manufacturing shop is investigated. }\end{array}$ \\
\hline \multirow{3}{*}{$\begin{array}{l}\text { Applications of the RFID } \\
\text { in industry } 4.0\end{array}$} & $\begin{array}{l}\text { Lechner et al. } \\
\text { (2016) }\end{array}$ & $\begin{array}{l}\text { Concept for an intelligent UHF RFID reader according to } \\
\text { the Ideas of Industry } 4.0 \text { is developed. }\end{array}$ \\
\hline & $\begin{array}{l}\text { Mehami et al. } \\
\text { (2018) }\end{array}$ & $\begin{array}{l}\text { Application of RFID systems in the smart automated } \\
\text { guided vehicles for manufacturing in the context of } \\
\text { Industry } 4.0 \text { is investigated. }\end{array}$ \\
\hline & Liu et al. (2018) & $\begin{array}{l}\text { CPS-Based smart warehouse for Industry } 4.0 \text { using } \\
\text { advanced RFID systems is investigated. }\end{array}$ \\
\hline \multirow{3}{*}{$\begin{array}{l}\text { Wireless sensor networks } \\
\text { in manufacturing systems }\end{array}$} & Gungor et al. (2009) & $\begin{array}{l}\text { Challenges, design principles, and technical approaches in } \\
\text { industrial wireless sensor networks is investigated. }\end{array}$ \\
\hline & Li et al. (2017) & $\begin{array}{l}\text { Methodology for monitoring manufacturing environment } \\
\text { by using wireless sensor networks and the internet of } \\
\text { things is developed. }\end{array}$ \\
\hline & Alfian et al. (2017) & $\begin{array}{c}\text { Integration of RFID, wireless sensor networks, and data } \\
\text { mining in an e-pedigree food traceability system is } \\
\text { investigated. }\end{array}$ \\
\hline \multirow{3}{*}{$\begin{array}{l}\text { Energy management in } \\
\text { RFID-sensor networks }\end{array}$} & Babayo et al. (2017) & $\begin{array}{l}\text { A Review on energy management schemes in energy } \\
\text { harvesting wireless sensor networks is presented. }\end{array}$ \\
\hline & $\begin{array}{l}\text { Dowling et al. } \\
\text { (2009) }\end{array}$ & $\begin{array}{l}\text { A major step forward for energy efficiency in home and } \\
\text { industrial applications using RFID-enabled temperature } \\
\text { sensing devices is developed. }\end{array}$ \\
\hline & Tao et al. (2016) & $\begin{array}{l}\text { Internet of Things in product life-cycle energy } \\
\text { management is presented. }\end{array}$ \\
\hline \multirow{3}{*}{$\begin{array}{l}\text { Production planning and } \\
\text { scheduling using RFID } \\
\text { Systems }\end{array}$} & $\begin{array}{c}\text { Oliveira et al. } \\
\text { (2015) }\end{array}$ & $\begin{array}{l}\text { An intelligent model for logistics management based on } \\
\text { geofencing algorithms and RFID technology is developed. }\end{array}$ \\
\hline & Fan et al. (2015) & $\begin{array}{l}\text { Impact of RFID technology on supply chain decisions } \\
\text { with inventory inaccuracies is presented. }\end{array}$ \\
\hline & David et al. (2012) & $\begin{array}{l}\text { Usage of RFID wireless identification technology to } \\
\text { support decision making in steel works is developed. }\end{array}$ \\
\hline \multirow{3}{*}{$\begin{array}{l}\text { Performance } \\
\text { improvement in } \\
\text { manufacturing systems }\end{array}$} & $\begin{array}{l}\text { Ali and Haseeb } \\
\text { (2019) }\end{array}$ & $\begin{array}{l}\text { RFID technology as a strategic tool towards higher } \\
\text { performance of supply chain operations in textile and } \\
\text { apparel industry of Malaysia is presented. }\end{array}$ \\
\hline & Nayak et al. (2015) & $\begin{array}{l}\text { To analyze and improve the production process of cloth } \\
\text { manufacturing industries, application of the RFID in } \\
\text { textile and clothing manufacturing systems is discussed. }\end{array}$ \\
\hline & $\begin{array}{l}\text { Vatankhah Barenji } \\
\text { and Vatankhah } \\
\text { Barenji (2017) }\end{array}$ & $\begin{array}{l}\text { Improving multi-agent manufacturing control system by } \\
\text { indirect communication based on ant agents is presented. }\end{array}$ \\
\hline
\end{tabular}




\section{CONCLUSION}

In the present research work, a review in recent development of the RFID based wireless communication in manufacturing systems is presented. Different topics in applications of RFID for developing the manufacturing systems is reviewed and discussed in order to provide a useful study for the researchers in the interesting field.

To enhance manufacturers' competitiveness through inventory and lead time reduction, the Just In Time (JIT) manufacturing systems can be developed using the RFID systems. In order to decrease the cost and time of material handling in the part manufacturing systems which has a big portion of product cost, the RFID systems can be applied.

The RFID can develop the lean manufacturing systems by tracking products and material flow in manufacturing systems in order to decrease cost of produced parts by minimizing the waste materials in part production process. The RFID are applied to the smart storage systems to obtained accurate data and improve the part production scheduling process. Thus, more efficient and effective methods for storing, picking and dispatching goods in part production process are introduced by applying RFID to the smart storage systems.

In order to increase efficiency in manufacturing systems supply chain management can be improved by applying the RFID systems. Assembly methods and strategies of part production process can be analyzed and modified using the advanced RFID systems in order to increase added values in part manufacturing processes. To increase accuracy in part production process, monitoring and controlling systems using the RFID can be implemented.

The RFID systems can be applied to the industry 4.0 to increase capabilities and flexibilities of the smart factories as well as intelligent manufacturing systems. To detect and obtain data from the products as well as material flow in manufacturing systems, wireless sensor networks (WSNs) can be deployed in order to increase accuracy in part production process.

To increase efficiency of energy consumption in production processes, energy management systems can be developed by using the RFID-sensor networks. Process of production planning and scheduling are developed by using the accurate date obtained from the RFID systems in order to achieve more added values in part production process. The performances of part manufacturing systems can be analyzed and modified by using the obtained data from the RFID systems. 
To present an intelligent manufacturing systems with a developed process planning system, smart storage can be connected via cloud manufacturing systems to the assembly methods and strategies of part production process. New generation of automation and control systems in manufacturing engineering can be presented using the RFID systems in order to develop the applications of computer integrated manufacturing in part production process.

Automated manufacturing systems with PLCs can be developed using the advanced RFID in order to increase accuracy and efficiency in part production process. To increase capabilities of fault detection and diagnosis in automated manufacturing systems, advanced RFID can be applied. As a result, fault diagnosis in dynamic manufacturing systems can be developed using the advanced RFID technology.

To increase power of manufacturing management in part production systems in terms of digital manufacturing, product realization process can be developed using the RFID systems. Control and resource allocation for the manufacture of products can be developed using the advanced RFID systems in order to increase added values in process of part production. In the advanced digital marketing systems, manufacturing products according to customer orders can be developed using the RFID systems to increase customer satisfaction in part production process. In competitive environment of marketing, manufacturing flexibility can be increased using advanced RFID systems in terms of competence, capability, and customer satisfaction enhancement in part production process.

Energy consumption in the material handling systems as well as assembly methods of part production can be analyzed and decreased using the advanced RFID systems. The advanced Computer Aided Process Planning (CAPP) can be generated using the obtained data of RFID systems in smart storage systems, material handling systems, assembly methods of part production and production monitoring and controlling systems. Cellular manufacturing systems can be developed using the advanced RFID systems in order to increase capabilities of part production systems in terms of group technology process of advanced CAPP.

Thus, efficiency and accuracy in process of part production can be increased. Application of the RFID systems in the security and reliability enhancement of workers in industrial productions can be discussed in order to increase workers safety in part production process. Application of fuzzy logic as well as optimization methods such as genetic algorithm in analysis process of obtained data from the RFID systems can be implemented in order to increase ability of part production analysis. 
Applications of virtual manufacturing systems in the RFID systems can be developed in order to analyze and modify the process of part production in virtual environments. Machining operations of hard to cut materials can be modified by monitoring and analyzing the cutting tool in machining operations using the RFID systems. As a result, cutting tool life in machining operations can be increased in order to decrease the cost of part production. The virtual manufacturing systems in the can be modified using the developed RFID systems to present an intelligent manufacturing systems as industry 4.0.

Green manufacturing systems can be developed using advanced RFID systems in order to decrease the environmental pollutions due to manufacturing engineering. The RFID systems can be connected by using web systems in order to share date between different applications of manufacturing systems. So, the advantages of different RFID systems can be increased in order to develop the process of part production. These are suggestions for the future research works in the research filed to develop the applications of RFID systems in the part manufacturing systems.

\section{REFERENCES}

Albrecht, J., Dudek, R., Auersperg, J., Pantou, R., \& Rzepka, S. (2015). Thermal and mechanical behaviour of an RFID based smart system embedded in a transmission belt determined by FEM simulations for Industry 4.0 applications. Paper presented at the 2015 16th International Conference on Thermal, Mechanical and Multi-Physics Simulation and Experiments in Microelectronics and Microsystems.

Alfian, G., Rhee, J., Ahn, H., Lee, J., Farooq, U., Ijaz, M. F., \& Syaekhoni, M. A. (2017). Integration of RFID, wireless sensor networks, and data mining in an e-pedigree food traceability system. Review of. Journal of Food Engineering. 212, 65-75.

Ali, A., \& Haseeb, M. (2019). Radio frequency identification (RFID) technology as a strategic tool towards higher performance of supply chain operations in textile and apparel industry of Malaysia. Review of. Uncertain Supply Chain Management. 7(2), 215-26.

Alsharif, M. H., Kim, S., \& Kuruoğlu, N. (2019). Energy harvesting techniques for wireless sensor networks/radio-frequency identification: A review. Review of. Symmetry. 11(7), 865.

Altaf, M. S., Bouferguene, A., Liu, H., Al-Hussein, M., \& Yu, H. (2018). Integrated production planning and control system for a panelized home prefabrication facility using simulation and RFID. Review of. Automation in construction. 85, 369-83.

Alyahya, S., Wang, Q., \& Bennett, N. (2016). Application and integration of an RFIDenabled warehousing management system-a feasibility study. Review of. Journal of Industrial Information Integration. 4, 15-25. 
Anjum, S. S., Noor, R. M., Anisi, M. H., Ahmedy, I. B., Othman, F., Alam, M., \& Khan, M. K. (2017). Energy management in RFID-sensor networks: Taxonomy and challenges. Review of. IEEE Internet of Things Journal. 6(1), 250-66.

Arkan, I., \& Van Landeghem, H. (2013). Evaluating the performance of a discrete manufacturing process using RFID: a case study. Review of. Robotics and ComputerIntegrated Manufacturing. 29(6), 502-12.

Ascher, A., Lechner, J., Nosovic, S., Eschlwech, P., \& Biebl, E. (2016). Localization of UHF RFID transponders regarding industry 4.0 scenarios using DoA estimation techniques. Paper presented at the Smart SysTech 2016; European Conference on Smart Objects, Systems and Technologies.

Aydos, T. F., \& Ferreira, J. C. (2016). RFID-based system for Lean Manufacturing in the context of Internet of Things. Paper presented at the 2016 IEEE International Conference on Automation Science and Engineering (CASE).

Babayo, A. A., Anisi, M. H., \& Ali, I. (2017). A review on energy management schemes in energy harvesting wireless sensor networks. Review of. Renewable and sustainable energy reviews. 76, 1176-84.

Barenji, R. V., Barenji, A. V., \& Hashemipour, M. (2014). A multi-agent RFID-enabled distributed control system for a flexible manufacturing shop. Review of. The International Journal of Advanced Manufacturing Technology. 71(9-12), 1773-91.

Brintrup, A., Ranasinghe, D., \& McFarlane, D. (2010). RFID opportunity analysis for leaner manufacturing. Review of. International journal of production research. 48(9), 2745-64.

Chai, J., Wu, C., Zhao, C., Chi, H.-L., Wang, X., Ling, B. W.-K., \& Teo, K. L. (2017).

Reference tag supported RFID tracking using robust support vector regression and Kalman filter. Review of. Advanced Engineering Informatics. 32, 1-10.

Chen, J. C., Cheng, C.-H., \& Huang, P. B. (2013). Supply chain management with lean production and RFID application: A case study. Review of. Expert Systems with Applications. 40(9), 3389-97.

Chen, J. C., Cheng, C.-H., Huang, P. B., Wang, K.-J., Huang, C.-J., \& Ting, T.-C. (2013). Warehouse management with lean and RFID application: a case study. Review of. The International Journal of Advanced Manufacturing Technology. 69(1-4), 531-42.

Chen, J. C., Wang, K. J., Cheng, C. H., Fang, Y. J., Sun, C. J., \& Chien, J. W. (2011). Logistics efficiency improvement with lean management and rfid application. Paper presented at the Key Engineering Materials.

Chen, K.-Y. (2012). Cell controller design for RFID based flexible manufacturing systems. Review of. International Journal of Computer Integrated Manufacturing. 25(1), 35-50. Chen, K. M., Chen, J. C., \& Cox, R. A. (2012). Real time facility performance monitoring system using RFID technology. Review of. Assembly Automation. 
Chen, L.-F., \& Chen, S.-J. (2017). A RFID-based JIT Application for Least Waiting Time for Dynamic Smart Diet Customers. Paper presented at the ITM Web of Conferences.

Chen, R.-S., Tu, M. A., \& Jwo, J.-S. (2010). An RFID-based enterprise application integration framework for real-time management of dynamic manufacturing processes. Review of. The International Journal of Advanced Manufacturing Technology. 50(9-12), 1217-34.

Cheung, Y., Choy, K., Lau, C., \& Leung, Y. (2008). The impact of RFID technology on the formulation of logistics strategy. Paper presented at the PICMET'08-2008 Portland International Conference on Management of Engineering \& Technology.

Choy, K. L., Ho, G. T., \& Lee, C. (2017). A RFID-based storage assignment system for enhancing the efficiency of order picking. Review of. Journal of Intelligent Manufacturing. 28(1), 111-29.

Chuu, S.-J. (2009). Selecting the advanced manufacturing technology using fuzzy multiple attributes group decision making with multiple fuzzy information. Review of. Computers \& Industrial Engineering. 57(3), 1033-42.

Cui, L., Zhang, Z., Gao, N., Meng, Z., \& Li, Z. (2019). Radio frequency identification and sensing techniques and their applications-A review of the state-of-the-art. Review of. Sensors. 19(18), 4012.

Dastres, R., \& Soori, M. (2020). Impact of Meltdown and Spectre on CPU Manufacture Security Issues. Review of. International Journal of Engineering and Future Technology. 18(2), 62-9.

Dastres, R., \& Soori, M. (2020). Secure Socket Layer in the Network and Web Security. Review of. International Journal of Computer and Information Engineering. 14(10), 330-3.

Dastres, R., \& Soori, M. (2021). Advanced Image Processing Systems. Review of. International Journal of Imaging and Robotics. 21(1).

Dastres, R., \& Soori, M. (2021). A Review in Recent Development of Network Threats and Security Measures. Review of. International Journal of Computer and Information Engineering. 15(1), 75-81.

David, J., Svec, P., Frischer, R., \& Stranavova, M. (2012). Usage of RFID wireless identification technology to support decision making in steel works. Paper presented at the 21st international conference on metallurgy and materials.

Ding, K., Jiang, P., \& Su, S. (2018). RFID-enabled social manufacturing system for interenterprise monitoring and dispatching of integrated production and transportation tasks. Review of. Robotics and Computer-Integrated Manufacturing. 49, 120-33.

Dowling, J., Tentzeris, M. M., \& Beckett, N. (2009). RFID-enabled temperature sensing devices: A major step forward for energy efficiency in home and industrial applications? 
Paper presented at the 2009 IEEE MTT-S International Microwave Workshop on Wireless Sensing, Local Positioning, and RFID.

Fan, T., Tao, F., Deng, S., \& Li, S. (2015). Impact of RFID technology on supply chain decisions with inventory inaccuracies. Review of. International Journal of Production Economics. 159, 117-25.

Ferdous, R. M., Reza, A. W., \& Siddiqui, M. F. (2016). Renewable energy harvesting for wireless sensors using passive RFID tag technology: A review. Review of. Renewable and sustainable energy reviews. 58, 1114-28.

Franceschini, F., Galetto, M., Maisano, D., \& Mastrogiacomo, L. (2009). A review of localization algorithms for distributed wireless sensor networks in manufacturing. Review of. International Journal of Computer Integrated Manufacturing. 22(7), 698-716.

Genovesi, S., Costa, F., Borgese, M., Dicandia, F. A., \& Manara, G. (2018). Chipless radio frequency identification (RFID) sensor for angular rotation monitoring. Review of.

Technologies. 6(3), 61.

Gotmare, A., Bokade, S., Inamdar, Z., \& Bhirud, S. (2019). A Systematic Literature Review on RFID Application in Manufacturing and Supply Chain Management. Review of. Industrial Engineering Journal. 12(10).

Gungor, V. C., \& Hancke, G. P. (2009). Industrial wireless sensor networks: Challenges, design principles, and technical approaches. Review of. IEEE Transactions on industrial electronics. 56(10), 4258-65.

Guo, Z., Ngai, E., Yang, C., \& Liang, X. (2015). An RFID-based intelligent decision support system architecture for production monitoring and scheduling in a distributed manufacturing environment. Review of. International Journal of Production Economics. 159, 16-28.

Haddud, A., \& Lee, H. (2013). Use of RFID technology in lean manufacturing: A survey on inventory management. Review of. International Journal of Management Theory and Practices. 14(1), 55-72.

He, W., Tan, E. L., Lee, E. W., \& Li, T. (2009). A solution for integrated track and trace in supply chain based on RFID \& GPS. Paper presented at the 2009 IEEE Conference on Emerging Technologies \& Factory Automation.

Huang, G., Wright, P., \& Newman, S. T. (2009). Wireless manufacturing: a literature review, recent developments, and case studies. Review of. International Journal of Computer Integrated Manufacturing. 22(7), 579-94.

Huang, G. Q., Qu, T., Zhang, Y., \& Yang, H. (2010). RFID-enabled real-time manufacturing for automotive part and accessory suppliers. Paper presented at the The 40th International Conference on Computers \& Indutrial Engineering. 
Huang, G. Q., Zhang, Y., Chen, X., \& Newman, S. T. (2008). RFID-enabled real-time wireless manufacturing for adaptive assembly planning and control. Review of. Journal of Intelligent Manufacturing. 19(6), 701-13.

Huang, G. Q., Zhang, Y., \& Jiang, P. (2007). RFID-based wireless manufacturing for walking-worker assembly islands with fixed-position layouts. Review of. Robotics and Computer-Integrated Manufacturing. 23(4), 469-77.

Iannello, F., Simeone, O., \& Spagnolini, U. (2010). Energy management policies for passive RFID sensors with RF-energy harvesting. Paper presented at the 2010 IEEE International Conference on Communications.

Jamaludin, Z., Huong, C. Y., Abdullah, L., Nordin, M. H., Abdullah, M., Haron, R., \& Jalal, K. (2018). Automated tracking system using RFID for sustainable management of material handling in an automobile parts manufacturer. Review of. Journal of Telecommunication, Electronic and Computer Engineering (JTEC). 10(1-7), 35-40.

Jardine, N., Gericke, G. A., Kuriakose, R. R., \& Vermaak, H. J. (2019). Wireless smart product tracking using radio frequency identification. Paper presented at the 2019 IEEE 2nd Wireless Africa Conference (WAC).

Jaska, P., Reyes, P., Zelbst, P. J., Green, K. W., \& Sower, V. E. (2010). Impact of RFID technology utilization on operational performance. Review of. Management Research Review.

Kassal, P., Steinberg, M. D., \& Steinberg, I. M. (2018). Wireless chemical sensors and biosensors: A review. Review of. Sensors and Actuators B: Chemical. 266, 228-45.

Lechner, J., Ascher, A., Nosovic, S., \& Guenthner, W. A. (2016). Concept for an intelligent UHF RFID reader according to the Ideas of Industry 4.0. Paper presented at the Smart SysTech 2016; European Conference on Smart Objects, Systems and Technologies.

Leung, J., Cheung, W., \& Chu, S.-C. (2014). Aligning RFID applications with supply chain strategies. Review of. Information \& Management. 51(2), 260-9.

Li, C. Z., Xue, F., Li, X., Hong, J., \& Shen, G. Q. (2018). An Internet of Things-enabled BIM platform for on-site assembly services in prefabricated construction. Review of. Automation in construction. 89, 146-61.

Li, W., \& Kara, S. (2017). Methodology for monitoring manufacturing environment by using wireless sensor networks (WSN) and the internet of things (IoT). Review of. Procedia CIRP. 61(Supplement C), 323-8.

Li, X., Li, D., Wan, J., Vasilakos, A. V., Lai, C.-F., \& Wang, S. (2017). A review of industrial wireless networks in the context of Industry 4.0. Review of. Wireless networks. 23(1), 23-41. 
Lim, M. K., Bahr, W., \& Leung, S. C. (2013). RFID in the warehouse: A literature analysis (1995-2010) of its applications, benefits, challenges and future trends. Review of. International Journal of Production Economics. 145(1), 409-30.

Lindblad, F., Bolmsvik, Å., Pettersson, J., \& Wiberg, S. (2018). Efficiencies in the on-site material handling process by using radio frequency identification in the wood building construction industry. Review of. Int. J. Innov. Manag. Technol. 9, 252-9.

Liu, G., Feng, J., Zhang, Y., Zhang, Z., Xie, D., \& Ai, Q. (2012). Management methods of electric vehicle batteries using RFID techniques. Review of. Journal of Electric Power, Science, and Technology. 27(3), 72-6.

Liu, G., Yu, W., \& Liu, Y. (2006). Resource management with RFID technology in automatic warehouse system. Paper presented at the 2006 IEEE/RSJ International Conference on Intelligent Robots and Systems.

Liu, W., Zheng, L., Sun, D., Liao, X., Zhao, M., Su, J., \& Liu, Y. (2012). RFID-enabled realtime production management system for Loncin motorcycle assembly line. Review of.

International Journal of Computer Integrated Manufacturing. 25(1), 86-99.

Liu, X., Cao, J., Yang, Y., \& Jiang, S. (2018). CPS-based smart warehouse for industry 4.0: a survey of the underlying technologies. Review of. Computers. 7(1), 13.

Lu, B., Bateman, R., \& Cheng, K. (2006). RFID enabled manufacturing: fundamentals, methodology and applications. Review of. International Journal of Agile Systems and Management. 1(1), 73-92.

Lu, S., Xu, C., Zhong, R. Y., \& Wang, L. (2017). A RFID-enabled positioning system in automated guided vehicle for smart factories. Review of. Journal of Manufacturing Systems. 44, 179-90.

Makris, S., Michalos, G., \& Chryssolouris, G. (2012). RFID driven robotic assembly for random mix manufacturing. Review of. Robotics and Computer-Integrated Manufacturing. 28(3), 359-65.

Mehami, J., Nawi, M., \& Zhong, R. Y. (2018). Smart automated guided vehicles for manufacturing in the context of Industry 4.0. Review of. Procedia manufacturing. 26, 107786.

Mejjaouli, S., \& Babiceanu, R. F. (2015). RFID-wireless sensor networks integration: Decision models and optimization of logistics systems operations. Review of. Journal of Manufacturing Systems. 35, 234-45.

Moon, S., Xu, S., Hou, L., Wu, C., Wang, X., \& Tam, V. W. (2018). RFID-aided tracking system to improve work efficiency of scaffold supplier: Stock management in Australasian supply chain. Review of. Journal of Construction Engineering and Management. 144(2), 04017115. 
Mourtzis, D., Vlachou, E., Milas, N., \& Dimitrakopoulos, G. (2016). Energy consumption estimation for machining processes based on real-time shop floor monitoring via wireless sensor networks. Review of. Procedia CIRP. 57, 637-42.

Musa, A., \& Dabo, A.-A. A. (2016). A review of RFID in supply chain management: 20002015. Review of. Global Journal of Flexible Systems Management. 17(2), 189-228.

Naskar, S., Basu, P., \& Sen, A. K. (2020). A literature review of the emerging field of IoT using RFID and its applications in supply chain management. Review of. Securing the Internet of Things: Concepts, Methodologies, Tools, and Applications. 1664-89.

Nayak, R., Singh, A., Padhye, R., \& Wang, L. (2015). RFID in textile and clothing manufacturing: technology and challenges. Review of. Fashion and Textiles. 2(1), 1-16.

Ngai, E., Chau, D., Poon, J., Chan, A., Chan, B., \& Wu, W. (2012). Implementing an RFIDbased manufacturing process management system: Lessons learned and success factors. Review of. Journal of Engineering and Technology Management. 29(1), 112-30.

Oghazi, P., Rad, F. F., Karlsson, S., \& Haftor, D. (2018). RFID and ERP systems in supply chain management. Review of. European Journal of Management and Business Economics.

Oliveira, R. R., Cardoso, I. M., Barbosa, J. L., da Costa, C. A., \& Prado, M. P. (2015). An intelligent model for logistics management based on geofencing algorithms and RFID technology. Review of. Expert Systems with Applications. 42(15-16), 6082-97.

Osyk, B. A., Vijayaraman, B., Srinivasan, M., \& Dey, A. (2012). RFID adoption and implementation in warehousing. Review of. Management Research Review.

Ota, N., \& Wright, P. (2006). Trends in wireless sensor networks for manufacturing. Review of. International Journal of Manufacturing Research. 1(1), 3-17.

Petrov, D., Schmidt, M., Hilleringmann, U., Hedayat, C., \& Otto, T. (2019). RFID based sensor platform for industry 4.0 application. Paper presented at the Smart Systems Integration; 13th International Conference and Exhibition on Integration Issues of Miniaturized Systems.

Qu, T., Yang, H., Huang, G. Q., Zhang, Y., Luo, H., \& Qin, W. (2012). A case of implementing RFID-based real-time shop-floor material management for household electrical appliance manufacturers. Review of. Journal of Intelligent Manufacturing. 23(6), 2343-56.

Qu, T., Zhang, L., Huang, Z., Dai, Q., Chen, X., Huang, G. Q., \& Luo, H. (2013). RFIDenabled smart assembly workshop management system. Paper presented at the 2013 10th IEEE International Conference On Networking, Sensing And Control (ICNSC).

Ramadan, M., Al-Maimani, H., \& Noche, B. (2017). RFID-enabled smart real-time manufacturing cost tracking system. Review of. The International Journal of Advanced Manufacturing Technology. 89(1-4), 969-85. 
Ramadan, M., Alnahhal, M., \& Noche, B. (2016). RFID-Enabled Real-Time Dynamic Operations and Material Flow Control in Lean Manufacturing. In Dynamics in Logistics, 281-90. Springer.

Sanpechuda, T., \& Kovavisaruch, L. (2008). A review of RFID localization: Applications and techniques. Paper presented at the 2008 5th International Conference on Electrical Engineering/Electronics, Computer, Telecommunications and Information Technology.

Saygin, C., \& Sarangapani, J. (2011). Radio Frequency Identification (RFID) enabling lean manufacturing. Review of. International Journal of Manufacturing Research. 6(4), 32136.

Sgarbossa, F., Peron, M., \& Fragapane, G. 2020. "Cloud Material Handling Systems: Conceptual Model and Cloud-Based Scheduling of Handling Activities." In Scheduling in Industry 4.0 and Cloud Manufacturing, 87-101. Springer.

Smith, A. D., Damron, T. S., Cockrell, S., \& Melton, A. M. 2018. "Radio Frequency Identification Systems Within a Lean Supply Chain in a Global Environment." In Encyclopedia of Information Science and Technology, Fourth Edition, 5516-26. IGI Global.

Soori, M., \& Arezoo, B. (2021). Virtual Machining Systems for CNC Milling and Turning Machine Tools: A Review. Review of. International Journal of Engineering and Future Technology. 1(18), 56-104.

Soori, M., Arezoo, B., \& Habibi, M. (2013). Dimensional and geometrical errors of three-axis CNC milling machines in a virtual machining system. Review of. Computer-Aided Design. 45(11), 1306-13.

Soori, M., Arezoo, B., \& Habibi, M. (2014). Virtual machining considering dimensional, geometrical and tool deflection errors in three-axis CNC milling machines. Review of. Journal of Manufacturing Systems. 33(4), 498-507.

Soori, M., Arezoo, B., \& Habibi, M. (2016). Tool deflection error of three-axis computer numerical control milling machines, monitoring and minimizing by a virtual machining system. Review of. Journal of Manufacturing Science and Engineering. 138(8).

Soori, M., Arezoo, B., \& Habibi, M. (2017). Accuracy analysis of tool deflection error modelling in prediction of milled surfaces by a virtual machining system. Review of.

International Journal of Computer Applications in Technology. 55(4), 308-21.

Soori, M., \& Asamel, M. (2020). Mechanical Behavior of Materials in Metal Cutting Operations, A Review. Review of. Journal of New Technology and Materials. 10(2). Soori, M., Asamel, M., \& Solyali, D. (2020). Recent Development in Friction Stir Welding Process: A Review. Review of. SAE International Journal of Materials and Manufacturing. 14(1), 18. 
Soori, M., \& Asmael, M. (2021). Classification of research and applications of the computer aided process planning in manufacturing systems. Review of. Independent Journal of Management \& Production. 12(5), 1250-81.

Sulaiman, S., Umar, U. A., Tang, S., \& Fatchurrohman, N. (2012). Application of radio frequency identification (RFID) in manufacturing in Malaysia. Review of. Procedia engineering. 50, 697-706.

SUN, D.-h., WANG, L., SONG, X.-X., \& YANG, F. (2010). RFID based automatic worker identification for lean production [J]. Review of. Modern Manufacturing Engineering. 12. Sun, H., Chang, Z., \& Mo, R. (2009). Monitoring and controlling the complex product assembly executive process via mobile agents and RFID tags. Review of. Assembly Automation.

Sun, M., Al-Sarawi, S. F., Ashenden, P., Cavaiuolo, M., \& Ranasinghe, D. C. (2017). A fully integrable hybrid power management unit for passive UHF RFID. Paper presented the 2017 IEEE International Conference on RFID (RFID).

Sung, W.-T., \& Lu, C.-Y. (2018). Smart Warehouse Management Based on IoT Architecture. Paper presented at the 2018 International Symposium on Computer, Consumer and Control (IS3C).

Tao, F., Wang, Y., Zuo, Y., Yang, H., \& Zhang, M. (2016). Internet of Things in product lifecycle energy management. Review of. Journal of Industrial Information Integration. 1, 26-39.

Tortorella, G. L., Giglio, R., \& Van Dun, D. H. (2019). Industry 4.0 adoption as a moderator of the impact of lean production practices on operational performance improvement. Review of. International journal of operations \& production management.

Trab, S., Bajic, E., Zouinkhi, A., Abdelkrim, M. N., \& Chekir, H. (2018). RFID IoT-enabled warehouse for safety management using product class-based storage and potential fields methods. Review of. International Journal of Embedded Systems. 10(1), 71-88.

Truong, N.-V., \& Vu, D.-L. (2012). Remote monitoring and control of industrial process via wireless network and Android platform. Paper presented at the 2012 International Conference on Control, Automation and Information Sciences (ICCAIS).

Vatankhah Barenji, A., \& Vatankhah Barenji, R. (2017). Improving multi-agent manufacturing control system by indirect communication based on ant agents. Review of.

Proceedings of the Institution of Mechanical Engineers, Part I: Journal of Systems and Control Engineering. 231(6), 447-58.

Wang, J., Luo, Z., \& Wong, E. C. (2010). RFID-enabled tracking in flexible assembly line. Review of. The International Journal of Advanced Manufacturing Technology. 46(1-4), 351-60.

Wang, K.-S. (2014). Intelligent and integrated RFID (II-RFID) system for improving traceability in manufacturing. Review of. Advances in Manufacturing. 2(2), 106-20. 
Wang, Y.-M., Wang, Y.-S., \& Yang, Y.-F. (2010). Understanding the determinants of RFID adoption in the manufacturing industry. Review of. Technological forecasting and social change. 77(5), 803-15.

Wong, W.-K., Guo, Z., \& Leung, S. (2014). Intelligent multi-objective decision-making model with RFID technology for production planning. Review of. International Journal of Production Economics. 147, 647-58.

Wright, P., Dornfeld, D., \& Ota, N. (2008). Condition monitoring in end-milling using wireless sensor networks (WSNs). Review of.

Wu, D., Liu, S., Zhang, L., Terpenny, J., Gao, R. X., Kurfess, T., \& Guzzo, J. A. (2017). A fog computing-based framework for process monitoring and prognosis in cybermanufacturing. Review of. Journal of Manufacturing Systems. 43, 25-34.

Xu, Y., \& Chen, M. (2016). Improving Just-in-Time manufacturing operations by using Internet of Things based solutions. Review of. Procedia CIRP. 56, 326-31.

Xu, Y., \& Chen, M. (2018). An Internet of Things based framework to enhance just-in-time manufacturing. Review of. Proceedings of the Institution of Mechanical Engineers, Part B: Journal of Engineering Manufacture. 232(13), 2353-63.

Yang, Z., Zhang, P., \& Chen, L. (2016). RFID-enabled indoor positioning method for a realtime manufacturing execution system using OS-ELM. Review of. Neurocomputing. 174, 121-33.

Yuan, L., Guo, Y., Wei, F., Lu, K., Jiang, J., \& Nian, L. (2017). Radio frequency identification-enabled monitoring and evaluating in the discrete manufacturing process. Review of. Proceedings of the Institution of Mechanical Engineers, Part B: Journal of Engineering Manufacture. 231(12), 2184-96.

Zelbst, P. J., Green, K. W., Sower, V. E., \& Reyes, P. M. (2012). Impact of RFID on manufacturing effectiveness and efficiency. Review of. International Journal of Operations \& Production Management.

Zhang, Y., Huang, G. Q., Qu, T., \& Ho, O. (2010). Agent-based workflow management for RFID-enabled real-time reconfigurable manufacturing. Review of. International Journal of Computer Integrated Manufacturing. 23(2), 101-12.

Zhang, Y., Jiang, P., \& Huang, G. (2008). RFID-based smart kanbans for just-in-time manufacturing. Review of. International Journal of Materials and Product Technology. 33(1-2), 170-84.

Zhang, Y., Jiang, P., Huang, G., Qu, T., Zhou, G., \& Hong, J. (2012). RFID-enabled realtime manufacturing information tracking infrastructure for extended enterprises. Review of. Journal of Intelligent Manufacturing. 23(6), 2357-66. 
Zhang, Y., Qu, T., Ho, O. K., \& Huang, G. Q. (2011). Agent-based smart gateway for RFIDenabled real-time wireless manufacturing. Review of. International journal of production research. 49(5), 1337-52.

Zhao, X., Zhang, W., Meng, H., He, F., \& Ren, S. (2018). A Framework for Shop Floor Material Delivery Optimization Based on RFID-Enabled Production Big Data. Paper presented at the International Conference on Intelligent and Interactive Systems and Applications.

Zheng, Y., Qiu, S., Shen, F., \& He, C. (2020). RFID-based material delivery method for mixed-model automobile assembly. Review of. Computers \& Industrial Engineering. 139, 106023.

Zhong, R. Y., Dai, Q., Qu, T., Hu, G., \& Huang, G. Q. (2013). RFID-enabled real-time manufacturing execution system for mass-customization production. Review of. Robotics and Computer-Integrated Manufacturing. 29(2), 283-92.

Zhong, R. Y., Huang, G. Q., Lan, S., Dai, Q., Zhang, T., \& Xu, C. (2015). A two-level advanced production planning and scheduling model for RFID-enabled ubiquitous manufacturing. Review of. Advanced Engineering Informatics. 29(4), 799-812.

Zhong, R. Y., Lan, S., Xu, C., Dai, Q., \& Huang, G. Q. (2016). Visualization of RFIDenabled shopfloor logistics Big Data in Cloud Manufacturing. Review of. The International Journal of Advanced Manufacturing Technology. 84(1-4), 5-16.

Zhong, R. Y., Li, Z., Pang, L., Pan, Y., Qu, T., \& Huang, G. Q. (2013). RFID-enabled realtime advanced planning and scheduling shell for production decision making. Review of. International Journal of Computer Integrated Manufacturing. 26(7), 649-62.

Zhong, R. Y., Xu, X., Klotz, E., \& Newman, S. T. (2017). Intelligent manufacturing in the context of industry 4.0: a review. Review of. Engineering. 3(5), 616-30.

Zhou, Z., Yao, B., Xu, W., \& Wang, L. (2017). Condition monitoring towards energyefficient manufacturing: a review. Review of. The International Journal of Advanced Manufacturing Technology. 91(9-12), 3395-415.

Zurawski, R. (2009). Keynote: Wireless sensor network in industrial automation. Paper presented at the 2009 International Conference on Embedded Software and Systems. 